\title{
Characteristic features of the second Karabakh war
}

\author{
Khayal Iskandarov ${ }^{1}$ A; Piotr Gawliczek 2 B \\ A War College of the Armed Forces, Republic of Azerbaijan \\ B University of Warmia and Mazury, Poland
}

Received: April 25, 2021 | Revised: June 8, 2021 | Accepted: June 30, 2021

DOI: $10.33445 /$ sds.2021.11.3.3

\begin{abstract}
The factors that led to the outbreak of the Second Karabakh War in late September, 2020 enshrined in the military history of Azerbaijan as a Patriotic War or "Operation Iron Fist" - have been clarified on the basis of retrospective analysis. The military-political processes that took place during the 44-day war have been studied, their characteristic features have been presented, the contributions of "Operation Iron Fist" to world's military art have been theoretically substantiated.
\end{abstract}

Key words: Second Karabakh War, "Operation Iron Fist", Patriotic War, 44-day war, NagornoKarabakh.

\section{Introduction}

In late September 2020, the "NagornoKarabakh conflict", which for various reasons had been ignored by international organizations for almost 30 years, flared up again and once again brought its existence to the attention of the world community. Azerbaijan had always preferred a peaceful solution to the conflict. Unfortunately, after the ceasefire agreement signed in May 1994, the process of negotiations on the settlement of the "Nagorno-Karabakh conflict" had not yield any results until an all-out war broke out. In fact, the Azerbaijani leadership had repeatedly stressed that if the talks failed, the conflict would have been resolved through war. Finally, the provocation of Armenian Armed Forces in the so called "front-line" prompted Azerbaijan to launch counteroffensive operation with a code name of "Operation Iron Fist" on September 27, 2020 and shattered the status quo over the NagornoKarabakh problem. One could say why the war started exactly in 2020, but not earlier, for instance in 2016, when a serious confrontation took place between the parties. It should be noted that, it had never been Azerbaijan's strategy to wage a war with "unknown results".
When we say "unknown results" it should not doubt or underestimate the capacity of Azerbaijan Armed Forces. Azerbaijan, in general, had braced itself for the war taking into account not only the strength of Armenia, but also the support of its foreign backers. It is an indisputable fact that without the foreign support, Armenia would have never been able to make unfounded claims against Azerbaijan.

The 44-day war has attracted the attention of various military experts and researchers worldwide. Researchers engaged in the field of defense and security try to draw conclusions about the nature of future wars by analyzing the experience of Azerbaijan. In particular, the effective use of unmanned aerial vehicles (UAV) by the Azerbaijan Army against the Armenian Armed Forces has led to serious discussions about outdated weapons and equipment, especially tanks, on the battlefield and the incompatibility of existing operational concepts with new technological capabilities. During the war and after the statement of November 10, 2020 on the ceasefire, a number of researchers, political and military experts touched upon various aspects of the Patriotic War, but no

\footnotetext{
${ }^{1}$ Corresponding author: e-mail: xayal1333@gmail.com, ORCID: 0000-0001-8975-6530
}

2 Assoc. Prof., PhD, e-mail: pgawliczek@gmail.com, ORCID: 0000-0002-0462-1168 
definitive study has been conducted yet. Therefore, the purpose of this paper is to study the military-political processes that took place during the Second Karabakh War, to make scientific and practical conclusions about its results. The paper analyzed the views and opinions of various experts and researchers, as well as the studies of various research centers. The work is mainly theoretical and uses methods of analysis, synthesis, induction, deduction and idealization.

\section{Results and discussion}

\section{Factors necessitating the outbreak of the Second Karabakh War}

Although there had been numerous clashes between the Armenian and Azerbaijani troops since the 1994 ceasefire agreement, the July 12, 2020 confrontation in the direction of Tovuz was of special historical significance. Because after that confrontation, the unity of the Azerbaijani people and their support for the army reached its peak, and there was a full stimulus to largescale counter-offensive operations against the provocations of the Armenian Army. A detailed information about this confrontation has been provided in different academic papers (Onvər Ofəndiyev və b.). In fact, Armenia wanted to ensure its policy of aggression on Azerbaijani lands by involving a third country in the conflict. However, the pragmatic behavior of the Azerbaijani leadership did not allow the Armenian government to realize this wish (Әnvər Әfəndiyev və b.).

The Armenian government, aggravated by the failure in Tovuz, began to concentrate its armed forces on the Armenian-Azerbaijani border, as well as in the occupied territories. There were intelligence reports that Armenia was planning an offensive against Azerbaijan to seize additional lands in order to extend socalled "security belt". The fact that YPG / PKK terrorists trained in Irag and Syria had been settled in the Nagorno-Karabakh region is another proof of our argument. While the world community thought that the Prime minister of Armenia, Nikol Pashinyan was "preparing his nation for peace", the Armenian government was preparing for war. Even in September 2020, during the 75th session of the UN General Assembly, the President of the Republic of Azerbaijan, Ilham Aliyev warned the international community that Armenia was preparing for a new war (Heydər Piriyev).

Damjan Miskovic presented the following chronological events that led to the outbreak of the Second Karabakh War, where he highlighted the importance of July 2020 military flare-up (Damjan Miskovic):

in late October 2018, Pashinyan told then U.S. National Security Adviser John Bolton that the resolution of the Nagorno-Karabakh conflict did not depend on the Armenian people and diaspora, because it was a pan-Armenian issue;

in late March 2019, then-Armenian Defense Minister David Tonayan called on the country to prepare for a "new war for new territories" after Prime Minister Nikol Pashinyan's first official meeting with President Ilham Aliyev;

in mid-May 2019, Pashinyan repudiatedthe Madrid Principles rejecting the existence of a key document for resolving the conflict;

in early August 2019, Pashinyan declared in the occupied Khankendi that Nagorno-Karabakh and seven surrounding regions were part of Armenia;

immediately after the July 2020 confrontation, Pashinyan stated that the "myth of the Azerbaijan Army capable of defeating the Armenian army in order to force Armenia to make concessions" no longer existed.

Finally, on September 27, 2020, the Armenian Armed Forces launched offensive operations along the entire front. However, the successful counter-offensive (codenamed "Iron Fist") by the Azerbaijan Armed Forces thwarted their plan to occupy new territories. Although the political nature of the war is presented complex in some sources, in fact, the "Operation Iron Fist" had a simple and explicit objective: to expel the units of Armenian Army from the 
occupied Azerbaijani lands and ensure the as "Operation Storm" initiated by Croatian Army return of about one million IDPs. In this respect, in August 1995 (Figure 1). the Second Karabakh War is of the same nature

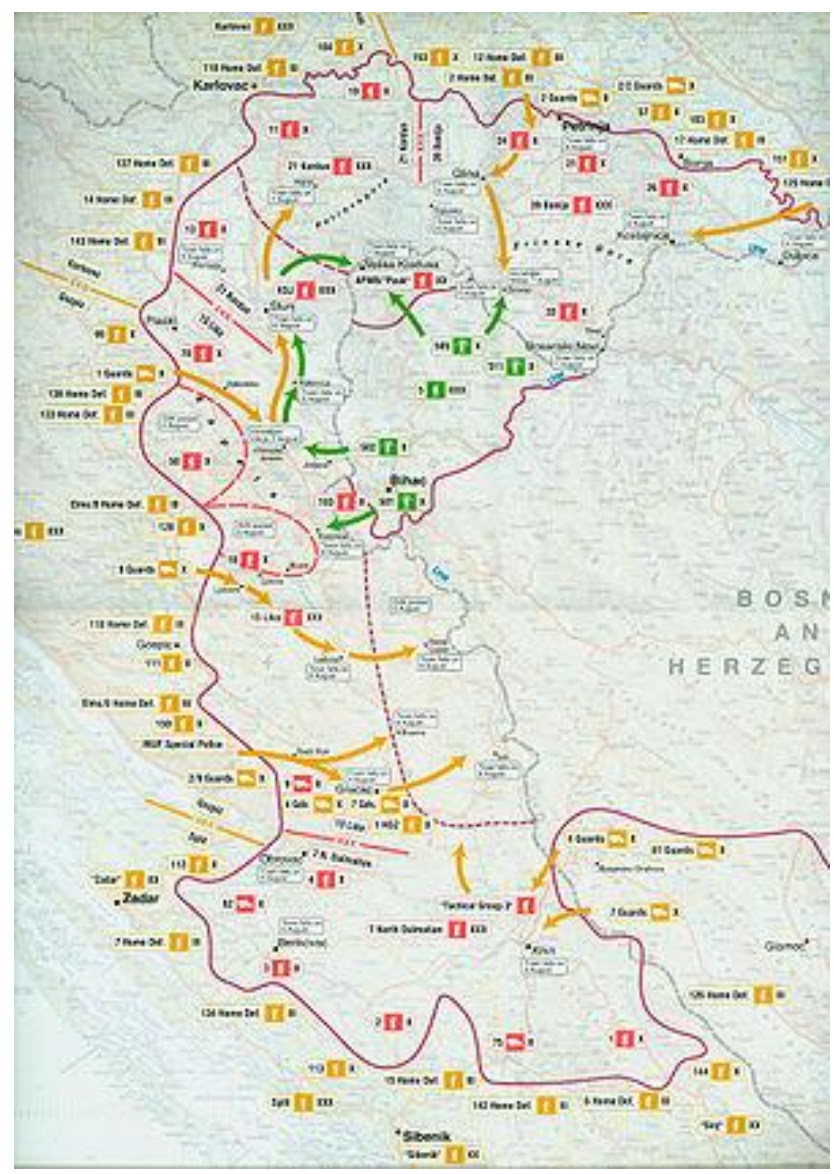

Fig. 1 - Operation Storm (Operation Storm)

In "Operation Storm", the Croatian Army overthrew the separatist regime in Serbian Krajina and restored the country's territorial integrity. Serbian Krajina was a so-called Serb state formed within Croatia's international borders. Its territory was $18.4 \%$ of the total territory of Croatia. However, the Second Karabakh War was a war waged by the Azerbaijan Army not only against the separatist regime in Nagorno-Karabakh, but also against the Armenian Army. It should also be noted that in this war, Armenia was not alone, foreign supporters backed up this country overtly (with political statements) and covertly (with the supply of weapons). The Armenian people hoped that Russia would intervene immediately and get them off the hook again. However, Russia did not openly intervene in the war, which dashed the hopes of the Armenian government and people, as well as the armenians living in Russia, especially the oligarchs.

One of the main differences between "Operation Iron Fist" and "Operation Storm" is that up to 200,000 serbs living in Serbian Krajina had fled. The rest (about 5,000-6,000) were almost older generation. Croatian historian Ivo Goldstein writes: "The reasons for the migration of serbs are different. Some were obliged to flee because the Serbian Army forced them to do so, while others fled in fear of retaliation by the Croatian Army or their Croatian neighbors, who had once been driven out and looted. However, later it became clear that this fear was unfounded" (C. Hurst \& Co. Publishers, 1999). In fact, the armenians in Karabakh also had such a fear. Because they also killed Azerbaijanis and looted their houses in early 1990s. However, the victorious Azerbaijani Army demonstrated its commitment to the principles of humanism only 
by striking at the legitimate military targets of the enemy.

Distinguishing characteristics of "Operation Iron Fist". Retrospective analysis

On September 27, 2020, the Armed Forces of the Republic of Azerbaijan mobilized its main forces for a counter-offensive operation. The primary objective of the operation was to dismantle the air defense systems of the Armenian Army. Because these systems played an important role in the detection and shooting of Azerbaijan's fighter jets and UAVs. However, as former US Ambassador to Azerbaijan Matthew Bryza noted, "it was not easy to dismantle these systems by drone or missile. From this point of view, the Azerbaijan Army demonstrated a very high level of skill in that situation" (Heydor Piriyev). It should be noted that the Armed Forces of the Republic of Azerbaijan used a unique method in order to locate enemy's air defense systems and surprised the military experts worldwide. The 1947 former soviet AN-2 aircrafts used in agriculture were flown unmanned with special equipment in their cockpits and the enemy having discovered and considered them modern UAVs, immediately tried to hit them with air defense systems, thus revealing their position. Dylan Malyasov notes that the Azerbaijan Armed Forces had more than 50 such AN-2 drones at Yevlakh Airport (Dylan Malyasov).

As a result, Azerbaijani drones destroyed enemy's air defense systems on the spot. When the Armenian Army realized that they were not modern UAVs, but AN-2 aircrafts, the Azerbaijan Army had already destroyed most of the air defense systems deployed by Armenia in Nagorno-Karabakh. After that, the fighter jets and UAVs of the Azerbaijan Armed Forces began to fly more safely in the airspace of NagornoKarabakh and destroy the enemy's armored vehicles and artillery. In early October, Russian military expert Igor Korotchenko shared his predictions about the war, emphasizing the scale of the operation: "Armenia's resources, including ammunition and fuel, will only be available for the next 2-3 weeks to continue the war with Azerbaijan. Without support, Yerevan will have nothing left to fight" (Russian military expert). The Second Karabakh War lasted two weeks longer than Igor Korotchenko estimated. Korotchenko argued that the war would be prolonged with foreign military support. It happened. Foreign supporters covertly backed up Armenia with weapons and equipment and therefore the war lasted relatively long. At this point, the analysis of the number of military equipment belonging to the Armenian Armed Forces is also important. The number of enemy equipment destroyed in the Second Karabakh War proved that the Republic of Armenia, with the foreign support, had become a serious security threat in the region, grossly violating the requirements of international conventions. While bringing the number of destroyed Armenian tanks to the people's attention, the President of the Republic of Azerbaijan Ilham Aliyev rightly asked: "How do they get so many tanks? Also, this contradicts international conventions. Why don't the organizations that are supposed to monitor these conventions pay no heed to it?" (Heydor Piriyev) In fact, this fact allows us to substantiate the arguments that Armenia was armed by foreign actors.

Irrespective of this fact, the Armed Forces of the Republic of Azerbaijan began to deplete the Armenian Army at the outset of the war. The Armenian Army, which had lost control of the occupied territories in the north and south, was in dire need of time and resources, forcing them to knock on the door of intermediaries to broker a ceasefire. A ceasefire agreement reached after 10 hours of talks in Moscow on October 10, brokered by Russian Foreign Minister Sergei Lavrov, allowed Armenia to mobilize resources and conduct operations to regain control of the lost territories. At the same time, politicians in some Western countries who depended on the armenian lobby and sought the support of armenians demonstrated double standards and accused Turkey of intervening in the war. This was exactly what Armenia wanted: to convince the world that Turkey was involved in the conflict and that it was the main reason for their failures on the battlefield. Undoubtedly, some countries which have conflicting interests with Turkey saw this moment as an opportunity and "believed" in such a "tale". In fact, the reality 
was far from what the Armenian government wanted to convey to the world community. First of all, the Azerbaijan Army conducted peace enforcement operations within its internationally recognized territories. The principled and constructive position of the Azerbaijani leadership on the NagornoKarabakh conflict, as well as the victories of the Army led to a completely new situation in the region. The party dictating the terms was Azerbaijan and Armenia had lost all chances to lay any conditions in the negotiations. This can be seen in President Ilham Aliyev's interviews with various influential television programs (Heydər Piriyev). If Nikol Pashinyan had pursued a provocative policy before the war began, from the second half of October, he only tried to save his government and did everything possible to do so. He first asked the Russian president to broker a ceasefire. Of course, this appeal aimed at gaining time. The Armenian leadership was not sincere and needed time to recuperate. However, that did not work either. Later, he exerted himself to physically involve ethnic armenians living abroad in the fight against the Azerbaijan Army in Nagorno-Karabakh. Why physically? It was apparent that the Armenian lobby had allocated colossal amount of money to the Armenian Armed Forces, however, even a large donation could not save them, since the resources of Armenian Army, including manpower had been exhausted. Therefore, the physical presence of foreign volunteers on the battlefield was extremely important for Armenia. Another reason for bringing volunteers from abroad to Nagorno-Karabakh was to draw the attention of the Armenian Diaspora to the conflict. Thus, Pashinyan wanted to create another image of "genocide" against "poor" armenians. If the attempt to create this image had not been successful, he would have been obliged to relinquish the post of prime minister as soon as possible or he would have faced the fate of the Armenian parliament of 1999. At the same time, the armenians would associate the loss of Nagorno-Karabakh with Pashinyan's reckless policy. As a result, Pashinyan had two options: 1) to sit at the negotiating table as a loser of the war and accept the terms of Azerbaijan; 2) to insist on fighting until the remaining Armenian forces were completely destroyed. Both options were not desirable for the Armenian government.

According to intelligence reports on October 20 and 21, the resistance of the Armenian Army was completely weakened. Thus, as a result of artillery strikes by the Azerbaijan Army, the vast majority of personnel of the 1st and 2nd motorized infantry regiments of the Armenian Armed Forces were destroyed. The personnel and combat equipment of the 1st motorized infantry battalion of the regiment were completely devastated, the 5th, 6th, 7th and 10th mountain regiments suffered heavy losses (up to two-thirds of the personnel) and were forced to withdraw. It should be noted that the high-ranking officers, such as Tatul Ghazaryan (commander of the 246th regiment), Armen Ohanyan (deputy commander of the 246th regiment), Hovik Melkumyan (deputy commander of the 1st regiment), Vahan Sargsyan (deputy commander of the mountain regiment) were among the dead. In addition, a legion of mercenaries stationed in the defensive zone of the 18th motorized infantry division and conscripts refused en masse to take part in the fighting, making the division withdraw. As a result of such measures taken by the Azerbaijan Army against the enemy, on October 21, the Prime Minister of Armenia Nikol Pashinyan put forward a proposal consisting of six steps: 1) create volunteer groups (minimum 30 people); 2) choose a commander from them; 3 ) apply to the military commissariat where the commander lives; 4) undergo training in one of the military units; 5) go to the front to defend the "homeland"; 6) win a victory. If we analyze it carefully, we would see that this appeal was just an expression of despair. From the first day when the Azerbaijani Army took the initiative on the battlefield, Armenian Armed Forces had bombed the settlements, targeting the civilian population, which was also an indication of this desperation. The analysis of the events that took place during that period shows that after the liberation of any city or settlement by Azerbaijan, the Armenian Army inevitably committed war crimes and targeted the human 
settlements. This can be compared to the behavior of Hitler's army in the last months of World War II. Hitler's foolish orders and weak decisions in World War II, allegedly to keep Germany afloat, were in fact the result of his earlier mistakes. Pashinyan was also on the agenda with such wrong decisions. Perhaps Pashinyan had not thought of the rapid advance of the Azerbaijan Army. Therefore, the situation prevented him from thinking normally and making decisions in the interest of his nation. Because collecting people from the streets and forcibly sending them to fight in Karabakh was not in the interests of the ordinary armenians. An analysis of the events that took place in the following days demonstrated that the situation in the Armenian Army had worsened after Nikol Pashinyan's unprofessional appeal to the people. Zachary Kallenborn described the situation as follows: "According to open sources, as of October 23, the Azerbaijani Armed Forces had destroyed at least 144 tanks, 35 PDMs, 19 ZTRs and 310 vehicles belonging to the Armenian army (in addition, dozens of artillery and air defense vehicles). In return, Azerbaijan's loss is considered negligible. Armenia has no choice but to make concessions" (Zachary Kallenborn). Apparently, Kallenborn did not rule out that Armenia had lost more by emphasizing the "open source information". As a result of a successful operation conducted by the Azerbaijan Army in the direction of Gubadli, the units of the Armenian Armed Forces were forced to withdraw from important heights and a number of positions (Figure 2). Serious blows were inflicted on the 155th artillery regiment, the 5th mountain regiment and the 543rd regiment located in the direction of Aghdara. Newly arrived volunteers at the enemy's artillery units north of Hadrut left the firing positions and began to flee. In the Khojavend, Fizuli and Gubadli directions of the front, the enemy's weapons, ammunition and fuel depots were destroyed and important communication lines were taken under control. Most of the conscripts sent to Nagorno-Karabakh from the Tsakhkadzor settlement of the Kotayk province of Armenia perished. Numerous enemy vehicles were destroyed in different directions of the front (Heydar Piriyev).

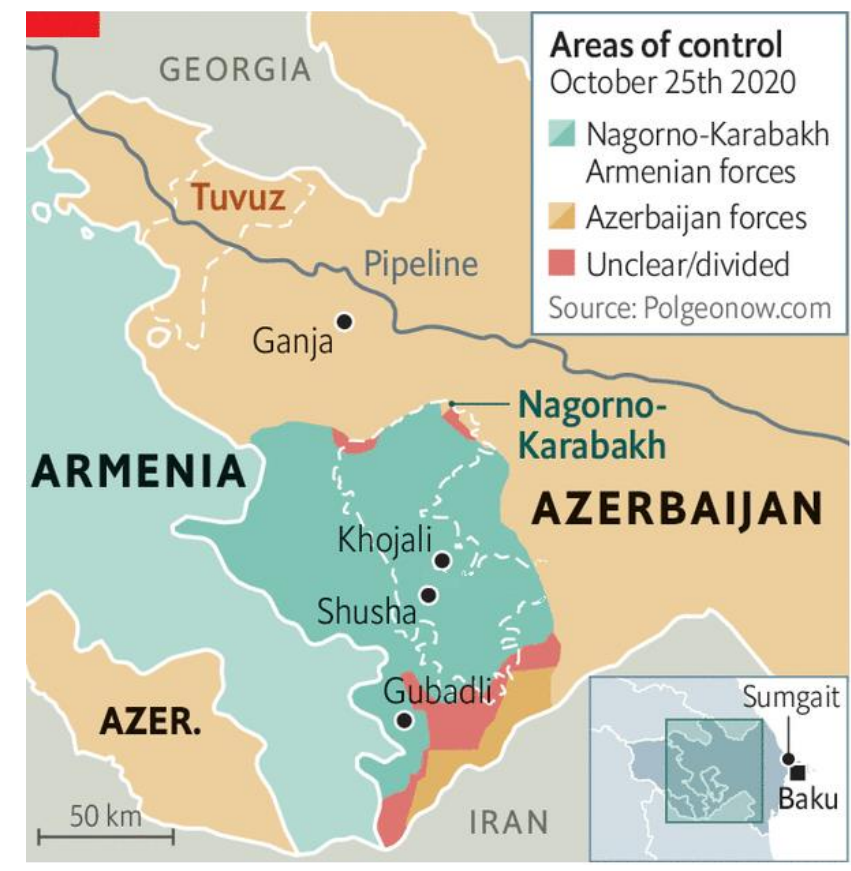

Fig. 2 - Situation in the front on October 25 (The fighting in Nagorno-Karabakh)

In fact, after the fortifications were breached, the military officials in Armenia knew that the situation would continue to deteriorate. It was obvious that, the military elite of the Armenian Army, led by the Minister of Defense, had deceived Pashinyan. The resignation of Minister of 
Defense Tonayan after war proves this fact. Pashinyan thought that the fortifications, built for several decades with the help of foreign supporters, would protect them from the attack of the Azerbaijan Army. However, his hopes were dashed. It should be noted that the same idea reassured Hitler in 1944. Thus, the Nazi army had prepared strong fortifications from the west coast of France to the coast of Norway against any possible attack by allied forces. This "Atlantic wall" was designed to protect the new German Empire from the Atlantic Ocean (Figure 3).

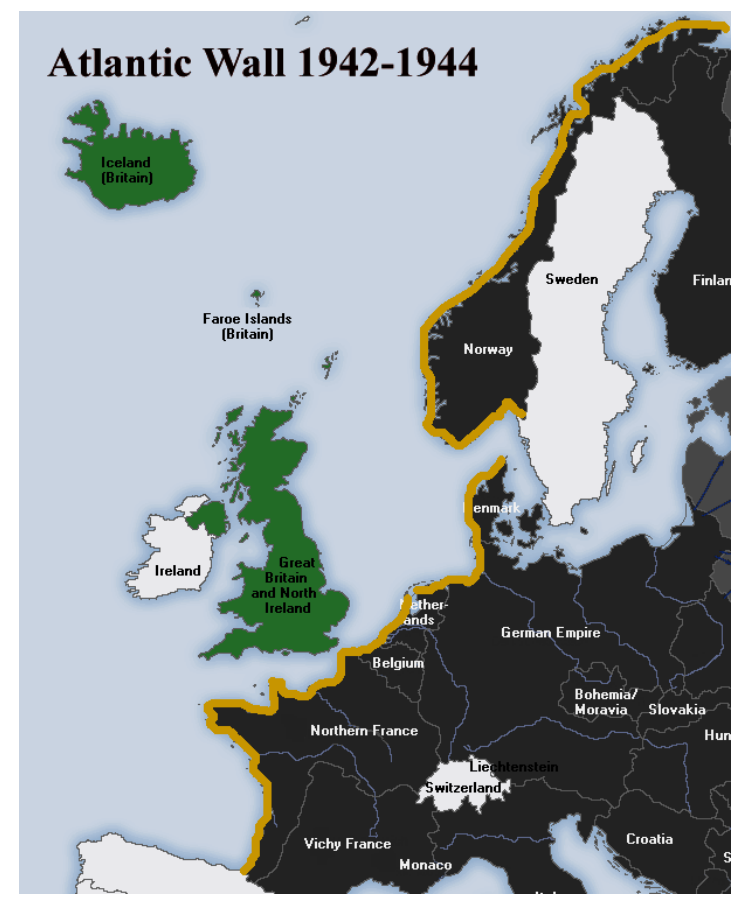

Fig. 3 - Atlantic wall (Operation Overlord \& Neptune)

However, this protective "wall" was ("Operation Overlord"), Hitler mistakenly destroyed in a very short time. On the eve of the thought that they would attack in the direction Allied landing on the beaches of Normandy of the city of Pas-de-Calais (Figure 4).

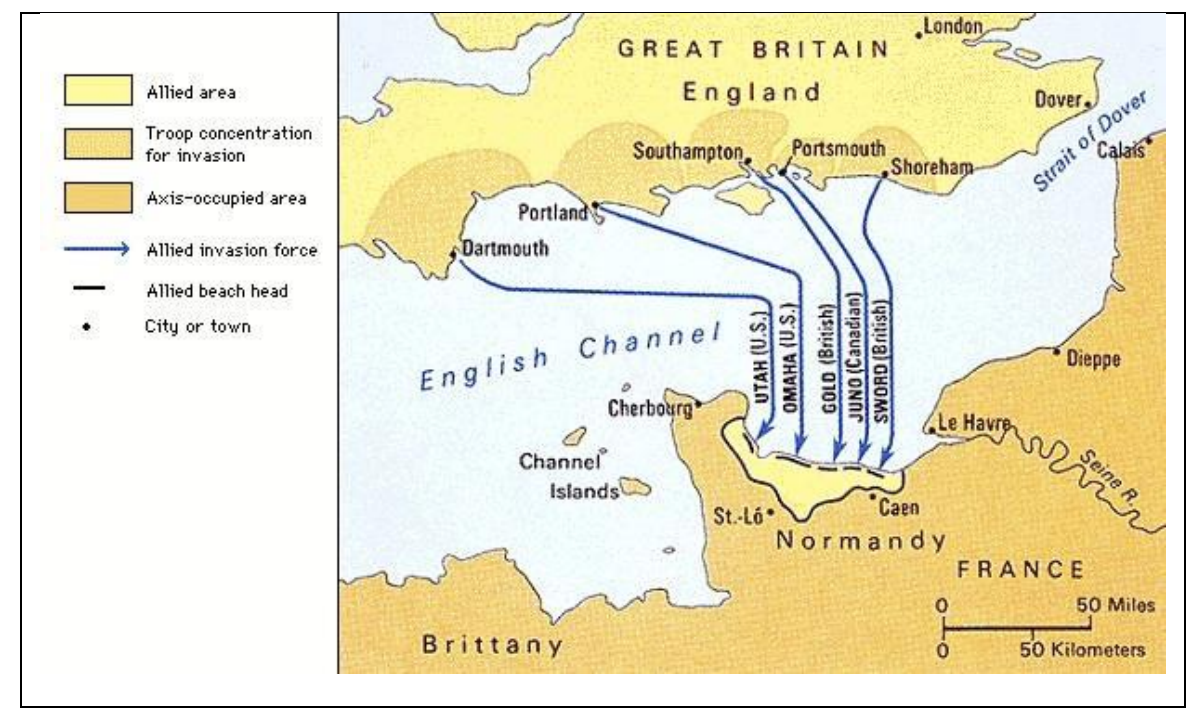

Fig. 4 - Operation Overlord (Operation Overlord)

To form such an idea, Allied forces carried out the attack ("Operation Overlord"). The "Operation Bodyguard" a few months before operation involved the creation of a fake 
"American Army Group" in that direction, the deployment of numerous models of tanks and armored vehicles, and the imitation of landing operations. The Germans thought that they had a fairly large spy network in the UK and that they had thorough information. However, prior to the operation, the vast majority of spies were identified and disbanded or forced to serve in the interest of allied forces (dual espionage). As a result of all these facts, the Germans were convinced that the attack of the allied forces would be launched in the direction of the Pasde-Calais. Eight tank divisions of the Nazi army were stationed in that area. The night before the attack, the Allied forces formed the idea of deploying a large number of paratroopers using balloons. Thus, the allied forces did not attack the city of Pas-de-Calais and by the time Hitler understood what was going on, the allied forces had already invaded the beaches and were advancing on French territory.

It should be noted that the Armenian Army also considered their fortifications "impregnable". However, the Azerbaijan Army breached these obstacles, including the "Ohanyan Wall" (Figure 4), within a day.

The political and military leadership of Azerbaijan, which predicted the attack of the Armenian Army, in fact carried out a deceptive activity similar to the "Operation Bodyguard". Thus, after the events of Tovuz in July 2020, the Armenian leadership formed the opinion that if the Armenian Army attacks, the Azerbaijani Armed Forces will counterattack in the direction of Aghdam. Thus, while the Armenians expected Azerbaijan to counterattack from the east of Nagorno-Karabakh, the Azerbaijan Army broke through the enemy's defense in the southeast and advanced to a depth of tens of kilometers in a short time (Figure 5).

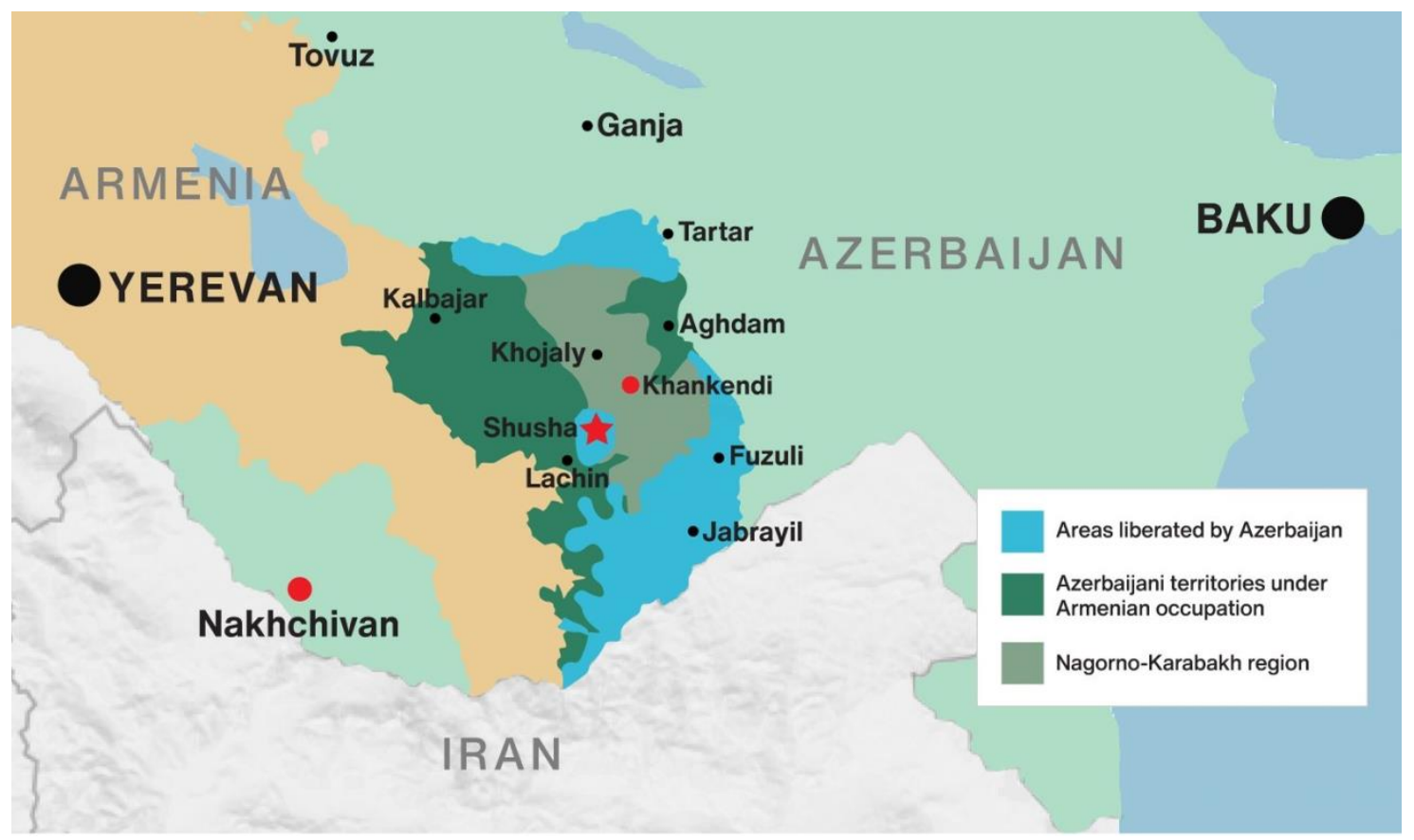

Fig. 5 - Situation in the front on November 8 (Azerbaijan liberates Shusha)

Thus, the strong fortifications built by Armenia in Aghdam practically lost their significance. During World War II, the US President Franklin Roosevelt said with regard to the defense of the Nazis: "Hitler built a fortress around Europe, but forgot to build a roof" (Robert Bateman). The same can be said about the Second Karabakh War. The Armenian Army did not take Azerbaijan's UAVs into account when building fortifications in the occupied territories. Thus, the Azerbaijan Army, which had already surprised the world with its success, pushed the enemy into a corner in all directions. It should also be noted that, the total number of Allied soldiers killed in Operation Overlord was about 2 to 2.5 times that of the Germans. Given 
that the attacking party was allied forces, such a ratio of losses was considered normal. However, in the "Operation Iron Fist" after the counteroffensive was launched, although the attacking party was Azerbaijan, the Armenian Armed Forces had lost not only 2.5-3 times less, but even 4-5 times more manpower. "Did Armenia have a chance to win this war by applying a different strategy?" Well-known US military expert Mikhail Kofman answered "no" to the question. According to the military expert, in this war, from the beginning to the end, Azerbaijan's advantage in terms of both quantity and quality had been observed (Michael Kofman).

It seems that the Armenian political leadership was wrong about the balance of military forces, opportunities and capabilities, as well as the organization of defense. With the liberation of Shusha on November 8, the Armenian government realized that all its efforts had been in vain and that it was inevitable to sign an act of capitulation. It should be noted that before the liberation of Shusha, the Armenian government and media were successful in deceiving the people with fake news. Thus, the officials of the Armenian Ministry of Defense announced that they were tactically withdrawing from the lands liberated by the Azerbaijan Army and even spread disinformation, denying the fact that some regions were liberated. For example, the Armenian side, which lost the city of Hadrut, tried to reduce the anxiety among the local audience by distributing old videos about the city. It should be highlighted that during the war, Armenian strategy of spreading "fake news" had worked non-stop. This was confirmed by the former military official Movses Hakobyan in his speech: "The lies spread during the 44-day war have plunged the country into a deep crisis. Although one of the tasks of the information center of the Armenian Ministry of Defense was to confuse the enemy, the number of lies should not have exceeded $30 \%$, but it was 100\%" (Murat Sofuoglu).

After the liberation of Shusha, it was no longer possible to spread such misinformation. Because the units of the Armenian Army stationed in Nagorno-Karabakh were almost under siege. Before the liberation of Shusha, Arayik Harutyunyan, the leader of the separatists in Nagorno-Karabakh told that the territories liberated by the Azerbaijani Armed Forces were "insignificant". Highlighting the importance of Shusha Harutyunyan said: "The party controlling Shusha controls NagornoKarabakh". Neil Hauer, a security expert who has analyzed the fighting for Shusha, estimated that the war should have ended in midNovember 2020. The researcher notes that "if the armenians can prevent the attack of the Azerbaijani Army in Shusha, they may have a chance to stabilize the situation. Surrounded by steep cliffs on three sides, Shusha is an almost natural fortress. No, if the Azerbaijan Army captures Shusha, they will be able to control the rest of Karabakh. As a result, it will be impossible for the armenians to recapture Shusha" (Neil Hauer). However, Shusha was liberated not in mid-November, but much earlier, on November 8 and this operation surprised all experts and has been engraved in the military history of the world. German military expert Ulrike Franke describes the liberation of Shusha as follows: "As you know, Shusha is located in a very strategic place, the area is mountainous. During the operation in Shusha, foggy air prevented the drones from flying. The Azerbaijan Army recaptured Shusha at the expense of special forces" (ikinci Qarabağ). According to a political commentator Gustav Gressel, the battle for Shusha showed that the armenians could not resist even in such a strategic area and that the Armenian Army was almost disintegrated, leaving them with no choice but to agree to a ceasefire statement (Gustav Gressel).

Thus, realizing that they had no other choice, the Armenian leadership agreed to sign an act of capitulation on November 10 and Azerbaijan's victory was unequivocally declared. Because from the first day of the war, President Ilham Aliyev said that the Azerbaijan Army could stand only in one case: the Armenian leadership should provide a schedule showing the exact time for the withdrawal of the occupying forces from the territory of Azerbaijan. It should be noted that all these points were reflected in the 
statement of November 10, 2020 (Figure 6).

Armenian forces to withdraw by 15 Nov

Armenian forces to withdraw by $1 \mathrm{Dec}$

Area of deployment for Russian peacekeepers
Armenian forces to withdraw by $20 \mathrm{Nov}$

Areas regained by Azerbaijan in the war

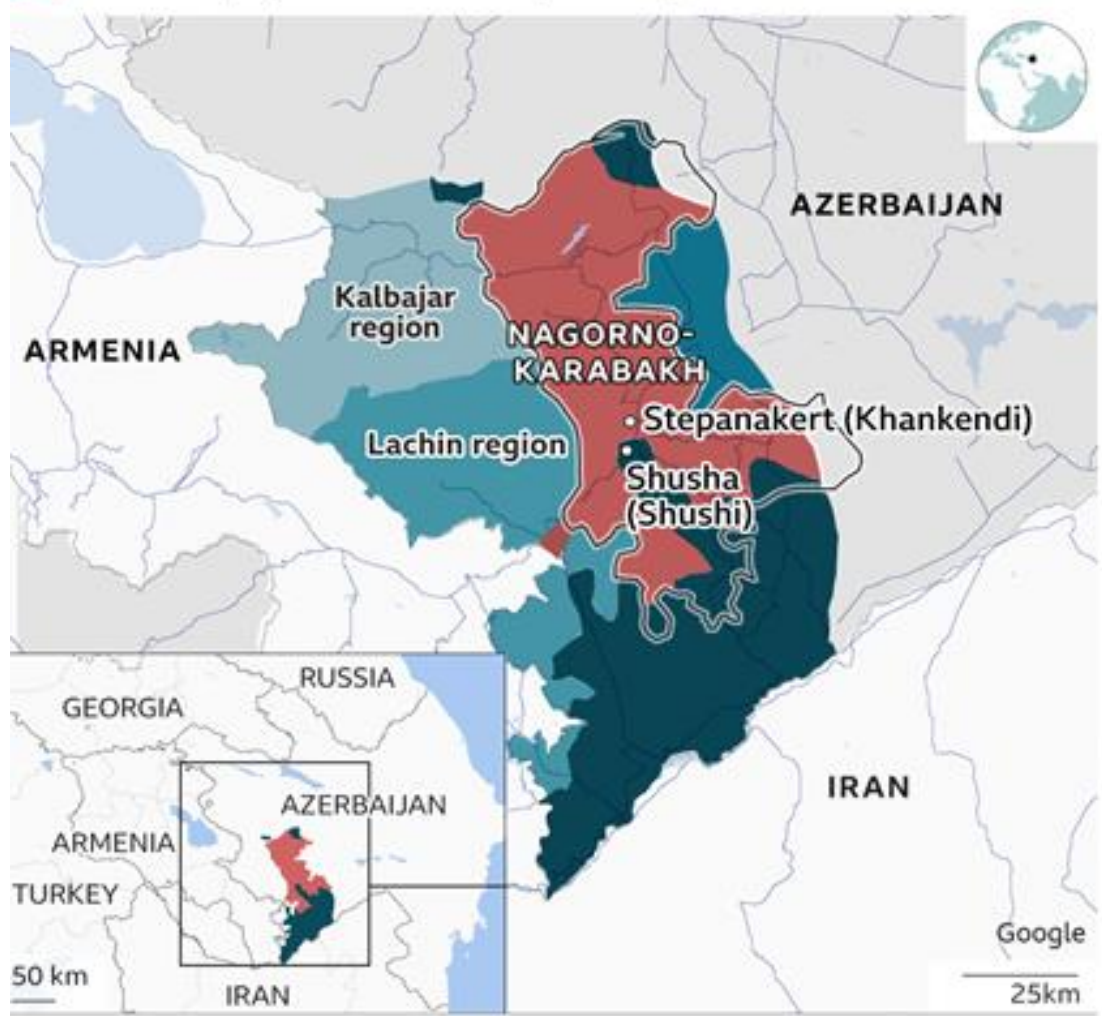

Fig. 6 - Situation in the front on November 10, 2020 (Armenia-Azerbaijan)

The number of soldiers serving in the occupied territories was recognized by the Armenian leadership at about 30,000 (Heydər Piriyev). It should be noted that the Armenian government was given an additional 10 days to evacuate the people from Kalbajar region. The evacuation of other districts was carried out on the dates specified in the statement. The incidents that took place after the November 10 Conclusions

The 44-day Patriotic War, enshrined in the military history of Azerbaijan, proved the will of the political leadership of the Republic of Azerbaijan and the military strength of the Armed Forces in the international arena. It is true that the Armenian Army was not weak, it was simply not able to satisfy the claims of the political and military leadership. Our analysis proves that the Azerbaijani Armed Forces did statement prove that some armed groups were not subject to the will of the Armenian political leadership. This fact necessitates the continuation of anti-terrorist operations in the liberated territories. In addition, those who are captured after the ceasefire should not be considered prisoners of war. Therefore, all arrested terrorists must be prosecuted under the legislation of the Republic of Azerbaijan.

not defeat a weak army presented by some experts, but an army that had been preparing for this war for years and had received sufficient support from foreign backers. Thus, "Operation Iron Fist", which is distinguished for its many specific features, will be the subject of many studies in the foreseeable future or even in the long run, attracting the attention of researchers and experts in security and military sciences. 


\section{References}

Armenia-Azerbaijan: Why did Nagorno-Karabakh spark a conflict? November 12, 2020. Available from: https://bbc.in/39BQrkK.

Azerbaijan liberates Shusha from 28 years of Armenian occupation. November 8, 2020. Available from : https://bit.ly/3eTjowO.

Bateman, Robert, No, Drones Haven't Made Tanks Obsolete Wrecked armor in the NagornoKarabakh conflict was down to bad training and terrain, not magical technology. October 15, 2020. Available from: https://bit.ly/3iwwQXj.

Goldstein, Ivo, Croatia: A History (C. Hurst \& Co. Publishers, 1999).

Gressel, Gustav, Military lessons from NagornoKarabakh: Reason for Europe to worry: [Electronic resource] - London, November 24, 2020. Available from: https://bit.ly/3d4PrZU.

Hauer, Neil, Nagorno-Karabakh conflict will soon face a decisive moment, November 06, 2020. Available from: https://bit.ly/363ikB9.

Iskandarov, Khayal, Sadi Sadiyev, The escalation on the border between Armenia and Azerbaijan: Possible reasons and implications, The European Geopolitical Forum, 06 August 2020. Available from: http://gpfeurope.com/forum/?blog=security\&id=360.

Kallenborn, Zachary, Drones are proving to have a destabilizing effect, which is why counterdrone systems should be a key part of us military aid to partners. December 9, 2020. Available from: https://bit.ly/201IFdc.

Kofman, Michael, A Look at the Military Lessons of the Nagorno-Karabakh Conflict. December 21, 2020. Available from: https://bit.ly/3rKzegw.
Malyasov, Dylan, Azerbaijani military turns Soviet biplane aircraft into drones. October 2, 2020. Available from: https://bit.ly/2Ntn9gV.

Miskovic, Damjan, Geopolitics and the Second Karabakh War, Caucasus Strategic Perspectives, Volume 1, Issue 2, (Winter 2020): 35-56.

Operation Overlord. Available from: https://bit.ly/391qITf

Operation Overlord \& Neptune D-day landings. Available from: https://bit.ly/3vMayqL.

Operation Storm. Available from: https://bit.ly/2P9QgX2.

Russian military expert talks ongoing situation in Nagorno-Karabakh conflict zone. 7 October 2020. Available from: https://bit.ly/3qM4YRX.

Sofuoglu, Murat, Why Azerbaijanis and Armenians have been fighting for so long: July 16, 2020. Available from: https://bit.ly/3shBsV3.

The fighting in Nagorno-Karabakh reflects decades of conflict, October 209, 2020, Available from: https://econ.st/2NWIcdn.

Әfəndiyev, Әnvər, Elnur Məmmədov, Arif Həsənov, Xəyal İskəndərov, Ermənistanın 2020-ci il iyul təxribatı: mümkün səbəb və təsirləri, Harbi bilik, No. 3 (2020): 5-10;

"ikinci Qarabağ müharibəsi tarixdə dronla qazanılmış ilk savaşdır" - Alman ekspert, 7 fevral, 2021. Available from: https://bit.ly/3d4TCVo.

Piriyev, Heydər, Rəşad Tahirov, Xəyal İskəndərov, 44-günlük Vətən Müharibəsi. Hərbi-siyasi təhlil, Milli tahlükasizlik va harbi elmlar, No. 1 (2021): 7-14. 